\title{
Performance of New Superior Varieties of Hybrid and Composite Corn in Papua
}

\author{
Fransiskus Palobo (Corresponding Author) \\ Researchers at the Papua Agricultural Technology Study Center. \\ Jalan Yahim Sentani -Jayapura 591235. Indonesia \\ E-mail: frans.merauke@gmail.com
}

\begin{abstract}
Siska Tirajoh
Associate expert researcher at the Papua Agricultural Technology Study Center.

Jalan Yahim Sentani -Jayapura 591235. Indonesia

E-mail: siskatirajoh2006@yahoo.com
\end{abstract}

\begin{abstract}
Merlin K.Rumbarar
Researchers at the Papua Agricultural Technology Study Center.

Jalan Yahim Sentani -Jayapura 591235. Indonesia

E-mail: merlinkornelia@pertanian.go.id
\end{abstract}

Muhammad Thamrin
Associate expert researcher and head of the Papua Agricultural Technology Study Center.

Jalan Yahim Sentani -Jayapura 591235. Indonesia

E-mail: tamrin6875@gmail.com

Received: Sep. 15, 2019

Accepted: Oct. 10, 2019

Published: Oct. 20, 2019

doi:10.5296/jas.v8i1.15445

URL: https://doi.org/10.5296/jas.v8i1.15445 


\section{Abstract}

One effort to increase corn production is through the use of new superior varieties (NSV) hybrid corn and composite corn. This study aims to determine the performance of growth and yields of four NSV hybrid corn and composite corn. The study was conducted in Merauke Regency, Papua since August to December 2018. The design used was Randomized Group Design (RGD) based on one factorial with 5 sub factors, each hybrid corn; HJ 21 Nasa variety, Nasa 29 variety and composite corn; Lamuru variety, Bisma variety, Sukmaraga variety. The results of the study at various ages of plant height were not affected significantly, the number of leaves were significantly affected by 30 days after planting (DAP) and at harvest time. Leaves width at various ages had no significant effect, while leaves length and stem diameter were all observed at the highest leaf length with the effect of 30 days after planting (DAP) Nasa $29(75 \mathrm{~cm})$ but 60 days after planting (DAP) and at harvest HJ 21 Agritan $93 \mathrm{~cm}$. Then the largest stem diameter of Nasa $29(1.7 \mathrm{~cm})$ was 30 days after planting (DAP) and 60 days after planting (DAP)- at harvest was each $2.5 \mathrm{~cm}$. Difference of the longest cob length of HJ 21 agritan $38.4 \mathrm{~cm}$, diameter of the largest cob $5.1 \mathrm{~cm}$, the highest number of lines per cob 15.8 seeds, the heaviest weight of $1000 \mathrm{HJ} 21$ Agritan $420.6 \mathrm{~g}$, heaviest dry harvest Nasa 29 (12.4 t/ha) and the heaviest dry pipelines Nasa 29 (9.2 t/ha). The overall performance of the results significantly affected both hybrid corn and composite corn.

Keywords: NSV, hybrid, composite

\section{Introduction}

Indonesia still importing corn in the last five years and this year the government was targeting no imports for the commodity. Import can be occurred because domestic corn production is only about 22 percent acceptable to animal feed mills and because of the low quality resulting some of the needs of these factories must be imported (Arifenie, 2013). The national corn production in 2015 was 19.61 million tons while the national corn demand was 16.30 million tons (Pusdatin, 2017). Thus, Indonesia should have a corn surplus about 3.31 million tons. However, Indonesia still imported corn approximately 2.40 million tons, because the demand for corn for the feed industry was 8.90 million tons (BPS, 2018)

The indicative targets for planting area, harvested area, productivity, and corn production in Papua in 2016 were 3,108 ha, 2,736 ha, 24.36 t/ha, and 6,666.02 tons, respectively (BPS, 2018). In the next 20 years, the use of corn for feed was expected to increase even after 2020 with estimation to be more than $60 \%$ of the total national needs. With the increasing needs for corn every year, the cultivation of corn was very profitable and had good prospects for those who work on it (Suryana, 2005 in Kaswan and Amzeri, 2011). Efforts to increase corn production can be achieved by using new superior varieties, optimal fertilization and regulation of planting population. Ministry of Agriculture's policy in 2014 was targeting hybrid corn cultivation to reach $75 \%$ (Sutarjo et al,. 2013).

Increased corn productivity could be done by combining superior varieties of hybrid corn and free-range using innovative technology that was more competitive through the model of corn Integrated Crop Management (Erawati et al., 2013). The Ministry of Agriculture continued to 
increase the production of corn commodities, especially to meet the increasing domestic demand from year to year. For livestock feed, demand for corn had reached more than $50 \%$ of national needs (Badan Litbang Pertanian, 2009). National corn production was determined by two main sources of growth, one of them was productivity growth. To stimulate increased productivity, technological innovation was needed, including the use of new superior varieties hybrid corn that had high potential result (Hosen, et al., 2013) and land management systems that were suitable for certain areas (Atman, 2015). National corn productivity was still low (4.90 t/ha) compared to its potential which reached $14.1 \mathrm{t} / \mathrm{ha}$ and the average productivity of research results reached $7.90 \mathrm{t} / \mathrm{ha}$ in paddy fields and $8.06 \mathrm{t} / \mathrm{ha}$ in dry land while in dry land under coconut trees productivity reached 6.20 t/ha (Atman, 2015).

Based on the explaining above, this study was conducted to determine the performance adaptability of hybrid and composite corn in Papua. It was hoped that this study was able to provide recommendations which hybrid and composite corn that adaptive on sub-optimal land.

\section{Research Methods}

\subsection{Material}

The new superior varieties of corn used in this study were HJ 21 Agritan hybrids, Nasa 29 hybrid, and Bisma Composites, Lamuru Composites, Sukmaraga Composites with basic seed level. The characteristics of the were shown in Table 1.

Table 1. Characteristics of new superior varieties of hybrid and composite corn

\begin{tabular}{|c|c|c|c|c|c|c|}
\hline \multirow{2}{*}{ No } & \multirow{2}{*}{ Parameter } & \multicolumn{5}{|c|}{ Variety } \\
\hline & & $\begin{array}{l}\text { HJ } 21 \\
\text { Agritan }\end{array}$ & Nasa 29 & Bisma & $\begin{array}{c}\text { Sukmarag } \\
\text { a }\end{array}$ & Lamuru \\
\hline 1 & Plant height $(\mathrm{cm})$ & 208,7 & 219 & 230 & 195 & 190 \\
\hline 2 & Weight of 1000 seeds (g) & 307 & 340,5 & 307 & 370 & 275 \\
\hline 3 & Productivity (ton/ha) & 5,7 & 11,9 & 5,7 & 6.6 & 5,6 \\
\hline 4 & $\begin{array}{l}\text { Potential result/yield } \\
\text { (ton/ha) }\end{array}$ & 7,5 & 13,7 & $7-7,5$ & 8,5 & 7,6 \\
\hline 5 & Year & 2014 & 2017 & 1995 & 2003 & 2000 \\
\hline
\end{tabular}

Source: Puslibangtan (2016)

\subsection{Research Location and Time}

The study was carried out in the Mekar Sari Farmer Group, Tanah Miring District, Merauke 
Regency, Papua in July - December 2018. The activity was carried out in dry land owned by farmers and 10 hectares of used land by involving farmer groups of 10 farmers.

\subsection{Research Methods}

The study used randomized group design (RGD) with the treatment of five (5) varieties, namely HJ 21 Agritan, Nasa 29, Bisma, Lamuru and Sukmaraga. In this study, farmers as a test with an area of $10 \mathrm{ha}$. The area of the study plot for each treatment was 1 ha. The technological components using the corn integrated plant management (IPM) approach including: (1) using new hybrid and composite superior corn varieties, (2) using a one-way tractor planting plant 4 rows of $75 \times 25 \mathrm{~cm}$, (3) applying inorganic fertilizer $(\mathrm{N}, \mathrm{P}$, and $\mathrm{K})$ based on the results of the soil analysis of the measurement results with the Rice-field Soil Test Kit (RSTK). The soil nutrient content in the assessment site included High for N, Medium for P and High for K. For fertilizing doses, as much as $200 \mathrm{~kg}$ ha-1 Urea, $100 \mathrm{~kg}$ ha-1 SP-36 and $50 \mathrm{~kg}$ ha-1 Ca were used. Fertilizer application was given based on the plant growth phase, which was given when the first corn fertilizer was 7-10 DAP and the second fertilization was 28-30 DAP. The types of fertilizers available in the field were Urea, SP-36, and Phonska. Based on the available fertilizer, the application for Urea $170 \mathrm{~kg}$ ha-1 was given three times (first fertilizing $100 \mathrm{~kg}$, second $70 \mathrm{~kg}$ ), SP-36 $70 \mathrm{~kg}$ ha-1 and Phonska $200 \mathrm{~kg}$ ha-1 given at the first fertilization together with urea (3) irrigation once a week, (5) weeding on 15 days after planting (DAP) and 30 days after planting (DAP) and (4) pest and disease control based on IPM concept. Every 10 rows of corn plants were made one channel or drainage that functions as irrigation or drainage when excessive rain. Provision of water for planting corn at the time before planting so that the land became moist. To control grasshoppers and corn-boring pests, Furadan 3G was given every shoot at the age of 14 days after planting (DAP).

\subsection{Research Parameters}

Observed data included agronomic data such as growth (plant height, number of leaves, leaves width, leaves length and stem diameter), yield performance included number of cob, cob diameter, cob length, number of rows per cob, number of seeds per row, dry harvest and Dry shelled ( $t$ ha-1) was done at harvest time. Calculation of each parameter, except productivity, was carried out on 10 plant samples with 3 replication and the yield was an average value. Productivity was calculated using a $2.5 \times 2.5 \mathrm{~m}$ fabric with 3 replications and the results were an average value.

\subsection{Statistic Analysis}

Data was processed using the $\mathrm{R}$ application version 3.5.2. Analysis of variance (Anova) was carried out to obtain an $\mathrm{F}$ test value at the $5 \%$ level, then proceed with further analysis based on the Least Significance Different (LSD) at the 5\% level. The results of agronomic and productivity parameters were compared with the average yield of these varieties to get a picture of the performance of adaptation in site-specific conditions in Merauke Regency. Correlation analysis was performed between observational parameters using the Pearson method. The difference in results was displayed as a percentage (\%) then calculated based on 
differences in agronomic parameters and the productivity of the performance of NSV adaptation to the characteristics of the NSV Corn.

\section{Results and Discussion}

\subsection{Growth Performance}

A good vegetative growth resulted a good generative growth, which were able to be seen from the length of the cob and the weight of 1000 seeds (Budiastuti, 2000). Based on the resulted of various plant height parameters and the number of corn leaves, the varieties had a significant effect on 30 days after planting (DAP). On the contrary, at the age of 60 days after planting (DAP) and before the harvest did not have a significant effect unless the number of leaves at harvest had a significant effect.

Table 2. Performance of crop height, number of Hybrid and Composite leaves

\begin{tabular}{lllllll}
\hline & \multicolumn{3}{c}{ Plant height (cm) } & \multicolumn{3}{c}{ Number of leaves (Strands) } \\
\cline { 2 - 7 } Treatment & 30 DAP & 60 DAP & When Harvest & 30 DAP & 60 DAP & When Harvest \\
\hline HJ 21 Agritan & $23,2 \mathrm{ab}$ & $143,2 \mathrm{a}$ & $147,6 \mathrm{a}$ & $8,6 \mathrm{ab}$ & $13,2 \mathrm{a}$ & $13,4 \mathrm{a}$ \\
Nasa 29 & $26,4 \mathrm{a}$ & $141,8 \mathrm{a}$ & $156,2 \mathrm{a}$ & $9,2 \mathrm{a}$ & $13,6 \mathrm{a}$ & $13 \mathrm{ab}$ \\
Bisma & $22,6 \mathrm{abc}$ & $142,2 \mathrm{a}$ & $150,6 \mathrm{a}$ & $8,8 \mathrm{ab}$ & $13,6 \mathrm{a}$ & $13,6 \mathrm{a}$ \\
Lamuru & $17,2 \mathrm{c}$ & $135,2 \mathrm{a}$ & $142,8 \mathrm{a}$ & $7,6 \mathrm{~b}$ & $12,8 \mathrm{a}$ & $12,4 \mathrm{~b}$ \\
Sukmaraga & $19,6 \mathrm{bc}$ & $161,2 \mathrm{a}$ & $161,8 \mathrm{a}$ & $7,6 \mathrm{~b}$ & $13,6 \mathrm{a}$ & $13,6 \mathrm{a}$ \\
\hline
\end{tabular}

Note: Numbers on the same line followed by the same letter are not significantly different in the LSD test on level $\alpha 5 \%$

In Table 2 the performance of the plant height growth of 30 DAP hybrid corn Nasa 29 variety $(26.4) \mathrm{cm}$. At 60 DAP after harvesting the highest composite corn was sukmaraga $161 \mathrm{~cm}$. The results of this study were almost the same as those reported by Kaihatu and Pesireron (2016) that the Sukmaraga variety had a good adaptability in relation to plant height where in the study on adaptation testing of some corn varieties on dry land agroecosystems in Maluku showed plant height at harvest were able to reach 276, $67 \mathrm{~cm}$. When compared to the description, it turned out that the overall NSV both hybrid and composite corn had plant height still further than the description, namely (Hj 21 Agritan), $219 \mathrm{~cm}$ (Nasa-29), $230 \mathrm{~cm}$ (Bhishma), $195 \mathrm{~cm}$ (Sukmaraga) and $190 \mathrm{~cm}$ (Lamuru) (Puslitbangtan, 2016). Meanwhile, the results of study in 2017 in Merauke Regency obtained a plant height of NSV of Nasa-29 by $128 \mathrm{~cm}$ (Palobo. Et al, 2017). That was, the height of the NSV of Nasa-29 plant was far different. According to Zamir et al., 2011 plant height was an important component to assist growth during the growing period, but plant height determined the adaptation of corn 
varieties to the growing environment but did not provide a positive correlation to productivity (Sarasutha, 2002).

The difference in plant height growth in each variety indicated a difference in growth vigor, meaning that the higher plant was more efficient utilizing sunlight so that it was able to produce more photosynthates that were useful for vegetative and generative growth of corn plants (Vivianthi, 2012). The greater the photosynthate produced by plants, the greater results of photosynthate which were transplanted to other parts of the plant, the results of photosynthesis were used by plants for plant growth and development processes which in turn were able to increase production (Probowati et al., 2014).

The number of leaves of 30 days after planting (DAP) was evident with an average of 7.6-9.2 strands, the highest value of Nasa 29 (9.2) the smallest were Lamuru and Sukmarga, each with 7.6 leaves. Then 60 DAP between 12.8 - 13.6 and just before harvest, with an average of 12.4 - 13.6 leaves. According to (Probowati et al., 2014) found in the leaves and stems that were transplanted when filling seeds had a role in increasing crop yields, so that if the results of photosynthate that were stored in the leaves and stems were high, the photosynthate that was transplanted when filling the seeds would be even higher.

Table 3. Performance of leaf width, leaf length, stem diameter of hybrid and composite corn

\begin{tabular}{|c|c|c|c|c|c|c|c|c|c|}
\hline \multirow[b]{2}{*}{ Treatment } & \multicolumn{3}{|c|}{ Leaf width (cm) } & \multicolumn{3}{|c|}{ Leaft length $(\mathrm{cm})$} & \multicolumn{3}{|c|}{ Stem Diameter $(\mathrm{cm})$} \\
\hline & $\begin{array}{l}30 \\
\text { DAP }\end{array}$ & $\begin{array}{l}60 \\
\text { DAP }\end{array}$ & $\begin{array}{l}\text { When } \\
\text { Harvest }\end{array}$ & $\begin{array}{l}30 \\
\text { DAP }\end{array}$ & $\begin{array}{l}60 \\
\text { DAP }\end{array}$ & $\begin{array}{l}\text { When } \\
\text { Harvest }\end{array}$ & $\begin{array}{l}30 \\
\text { DAP }\end{array}$ & $\begin{array}{l}60 \\
\text { DAP }\end{array}$ & $\begin{array}{l}\text { When } \\
\text { Harvest }\end{array}$ \\
\hline $\mathrm{HJ}$ & & & & & & & & & \\
\hline Agritan & $7,2 \mathrm{a}$ & $9,9 \mathrm{a}$ & 9,9a & $64,6 b$ & $93 a$ & $93 a$ & $1,36 a b$ & $2,2 \mathrm{ab}$ & $2,2 \mathrm{ab}$ \\
\hline Nasa 29 & $7,8 \mathrm{a}$ & $10,1 \mathrm{a}$ & $10,1 \mathrm{a}$ & $75 \mathrm{a}$ & $92,2 \mathrm{a}$ & $92,2 \mathrm{a}$ & $1,7 \mathrm{a}$ & $2,5 \mathrm{a}$ & $2,5 \mathrm{a}$ \\
\hline Bisma & $7,4 a$ & $9,4 \mathrm{a}$ & $9,4 a$ & $56,6 \mathrm{bc}$ & $90,8 \mathrm{ab}$ & $90,8 \mathrm{ab}$ & $1,3 \mathrm{ab}$ & $1,9 \mathrm{a}$ & $1,98 \mathrm{a}$ \\
\hline Lamuru & $6,6 a$ & $9,3 \mathrm{a}$ & $9,3 \mathrm{a}$ & $47,2 \mathrm{c}$ & $80,4 b$ & $80,4 b$ & $0,74 \mathrm{c}$ & $2 b$ & $2 b$ \\
\hline Sukmaraga & $6,8 \mathrm{a}$ & $9,4 \mathrm{a}$ & $9,4 a$ & $61,8 b$ & $92 \mathrm{a}$ & $92 \mathrm{a}$ & $1,24 b$ & $2,3 \mathrm{a}$ & $2,32 \mathrm{a}$ \\
\hline
\end{tabular}

Note: Numbers on the same line followed by the same letter were not significantly different in the LSD test on level $\alpha 5 \%$

Table 3 showed that the growth in leaf width of 30 DAP until harvest had no significant effect, where the widest hybrid corn variety of Nasa 29 was $7.8-10.1 \mathrm{~cm}$ and the smallest was composite lamuru variety $6.6-9.3 \mathrm{~cm}$. Leaves length 30 DAP significant effect, where the longest hybrid corn varieties Nasa $29(75) \mathrm{cm}$ followed by HJ 21 Agritan $64.6 \mathrm{~cm}$ then composite corn Sukmaraga variety $61.8 \mathrm{~cm}$ followed by bisma $56.6 \mathrm{~cm}$ and the shortest 
Lamuru $47.2 \mathrm{~cm}$. At 60 DAP it had a significant effect, where the longest hybrid HJ 21 Agritan $93 \mathrm{~cm}$ followed by NASA $29(92.2) \mathrm{cm}$, then Sukmaraga composite $92 \mathrm{~cm}$ followed by Bhishma $90.8 \mathrm{~cm}$ and the shortest lamuru $80.4 \mathrm{~cm}$. Observations at harvest were significant, where the longest hybrid HJ 21 leaves were $93 \mathrm{~cm}$ followed by Nasa $29(92.2) \mathrm{cm}$ and the longest composite Sukmaraga $92 \mathrm{~cm}$ followed by Bhishma $90.8 \mathrm{~cm}$ the shortest was Lamuru $80.4 \mathrm{~cm}$.

Stem diameter significantly affected observations of 30 DAP, 60 DAP and at harvest, where 30 DAP was the largest stem circumference of hybrid corn of Nasa 29 (1.7) cm and the smallest composite circumference of Lamuru was $0.7 \mathrm{~cm}$. Age 60 DAP and at harvest showed hybrid Nasa 29 variety $(2.5) \mathrm{cm}$ and the smallest composite stem circumference of Bisma variety $1.9 \mathrm{~cm}$.

\subsection{Performance Results}

The performance of several yield components was presented in Table 3, it was able seen that the length of the cobs, the diameter of the cobs and the number of rows per-cobs of all corn varieties tested showed a real effect. The length of the cobs ranged from 16.94 to $38.4 \mathrm{~cm}$. The results showed the hybrid corn cobs were longer varieties of HJ 21 Agritan $38.4 \mathrm{~cm}$, Nasa 29 (20) cm compared to the composite corn respectively Bisma $17.7 \mathrm{~cm}$, Lamuru 18, 9 $\mathrm{cm}$ and $16.9 \mathrm{~cm}$. The cob dimensions range from 4.5-5.06 cm, hybrid corn and composite were not much different in the circumference of the cob. The number of rows per cob was 13.2-15.8 seeds, showing less hybrid corn than composite rows with total rows. According to Robi'in (2009), the length and diameter of the cob was closely related to the yield of a variety.

Table 4. Performance of cob length, ear diameter, number of lines per cob with hybrid and composite corn

\begin{tabular}{lccc}
\hline Treatment & Cob Length $(\mathrm{cm})$ & Cob Diameter $(\mathrm{cm})$ & $\begin{array}{c}\text { Number of rows per Cob } \\
(\text { Seeds })\end{array}$ \\
\hline $\begin{array}{l}\text { HJ } \\
\text { Agritan }\end{array}$ & $38,4 \mathrm{a}$ & $5,06 \mathrm{ab}$ & $14 \mathrm{bc}$ \\
Nasa 29 & $20 \mathrm{ab}$ & & $14 \mathrm{bc}$ \\
Bisma & $17,7 \mathrm{~b}$ & $4,74 \mathrm{bc}$ & $15,3 \mathrm{ab}$ \\
Lamuru & $18,9 \mathrm{ab}$ & $4,9 \mathrm{~b}$ & $15,8 \mathrm{a}$ \\
Sukmaraga & $16,9 \mathrm{~b}$ & $5,3 \mathrm{a}$ & $13,2 \mathrm{c}$ \\
\hline
\end{tabular}

Note: Numbers on the same line followed by the same letter were not significantly different in the LSD test on level $\alpha 5 \%$

In Table 4 showed that the longest cob Hj 21 Agritan $38.4 \mathrm{~cm}$ and the shortest Sukmaraga 
$16.9 \mathrm{~cm}$. The biggest cobs of Lamuru are $5.3 \mathrm{~cm}$ and the smallest is Sukmaraga $4.5 \mathrm{~cm}$. Then the number of lines per cob was at most 15.8 seeds Lamuru and at least 13.2 seeds Sukmaraga. When compared the same with the description of the number of lines per COB approaching HJ 21 Agritan (14-16 lines), Nasa 29 (14-18 lines), Bisma (12-18 lines), Lamuru (12-16 lines) and Sukmaraga (12- 16 line) (Balitsereal, Puslitbangtan, 2012).

1000 seed weights, it appeared that all the varieties tested showed a real effect. The weight of 1000 seeds ranged from 215.8 to $420.6 \mathrm{~g}$, the heaviest weight of 1000 seeds was shown by HJ 21 Agritan (420.6 g) followed by Nasa 29 (329.6 g) and significantly different from other treatments namely Sukmaraga (260 g) , Lamuru (248 g) and Bisma (215.8 g), but when compared to the weight gain of 1000 seeds obtained by the Nasa 29, Bisma, Lamuru and Sukmaraga varieties were lower than the description, namely the Nasa 29 variety (340.5 g), Bisma (307 g), Lamuru (307 g) while the two other varieties exceed the weight of the description, namely Nasa 29 (340.5 g) and Sukmaraga (270 g) (Puslitbangtan, 2016). According to Takdir et al (2007), planting with cob diameter and weight of 100 seeds gave high seed yields.

Table 5. Performance / Severity of 1000, Dry Harvest and Dry Hybrid Corn and Composite Pipil

\begin{tabular}{l|c|c|c}
\hline Treatment & Weight $1000(\mathrm{~g})$ & Dry Harvest (t/ha) & dry shelled (t/ha) \\
\hline HJ 21 Agritan & $420,6 \mathrm{a}$ & $8,8 \mathrm{~b}$ & $6,3 \mathrm{~b}$ \\
\hline Nasa 29 & $329,6 \mathrm{~b}$ & $12,4 \mathrm{a}$ & $9,2 \mathrm{a}$ \\
\hline Bisma & $215,8 \mathrm{e}$ & $7,7 \mathrm{c}$ & $5,3 \mathrm{e}$ \\
\hline Lamuru & $248,2 \mathrm{~d}$ & $8,8 \mathrm{~b}$ & $5,8 \mathrm{c}$ \\
\hline Sukmaraga & $260 \mathrm{c}$ & $7,6 \mathrm{c}$ & $5,5 \mathrm{~d}$ \\
\hline
\end{tabular}

Note: Numbers on the same line followed by the same letter were not significantly different in the LSD test on level $\alpha 5 \%$

Dry Harvests of all the tested varieties showed a real effect. Dry harvest ranged from 7.6 to $12.4 \mathrm{t} / \mathrm{ha}$, the highest dry weight of harvest Nasa 29 (12.4) $\mathrm{t} /$ ha followed by Hj 21 Agritan, Lamuru each (8.8) $\mathrm{t} / \mathrm{ha}$, bisma $(7,7) \mathrm{t} / \mathrm{ha}$ and the smallest sukmaraga (7.6) t/ha. Dry harvesting process to dry pipil showed that the variable was very influential on the weight of dry shelled corn. For this reason, the higher the corn plant was going to be followed by an increase in dry shell weight, because plant height was a characteristic of plants that affects the plant growth process. The process absorbed a lot of nutrients or nutrients, so that plant cells were going to grow or increase in height, ultimately resulting in higher dry shell yield (Supriyadi et al., 2013). Dry pipil varieties tested showed all significant effects. The highest dry shelled weight Nasa 29 (9.2) t/ha followed by HJ 21 Agritan (6.3) t/ha, Lamuru (5.8) t/ha, 


\section{Macrothink}

Sukmaraga (5.5) t/ha and the smallest Bisma ( 5,3) t/ha. Purba (2014) reported that the adaptation test of the Lamuru variety in West Kalimantan had a similar production yield of $5.08 \mathrm{t} / \mathrm{ha}$ while in a study conducted in Merauke Regency showed a slightly higher yield of $5.8 \mathrm{t} / \mathrm{ha}$. While the results of the study of Handoko and Mulyadi (2017) reported that the production of Nasa 29 was adapted to sub-optimal land in Tanjung Jabung Timur, Jambi has a yield of 6.92 t/ha dry shelled. Palobo et al (2018) research results on composite corn farming in the border area of Jayapura City the highest yield of 6.4 t/ha dry shelled.

\subsection{Correlation Between Parameters}

Table 6 presented the correlations between growth performance and outcome parameters. Correlation tests showed that dry harvest correlated strongly, positively and differs markedly with stem diameter and number of cobs row.

Table 6. Correlations between parameters

\begin{tabular}{|c|c|c|c|c|c|c|c|c|c|c|c|}
\hline Parameter & $\begin{array}{l}\text { Height } \\
\text { plant } \\
(\mathrm{cm})\end{array}$ & $\begin{array}{l}\text { Number } \\
\text { of } \\
\text { leaves } \\
\text { (strands) }\end{array}$ & $\begin{array}{l}\text { Leaf } \\
\text { width } \\
(\mathrm{cm})\end{array}$ & $\begin{array}{l}\text { Leaft } \\
\text { length } \\
(\mathrm{cm})\end{array}$ & $\begin{array}{l}\text { Stem } \\
\text { Diameter } \\
\text { (cm) }\end{array}$ & $\begin{array}{l}\text { Length } \\
\text { cob } \\
(\mathrm{cm})\end{array}$ & $\begin{array}{l}\text { Cob } \\
\text { Diamter } \\
(\mathrm{cm})\end{array}$ & $\begin{array}{l}\text { Number } \\
\text { of } \\
\text { Lines } \\
\text { (Biji) }\end{array}$ & $\begin{array}{l}\text { Weight } \\
\text { (g) }\end{array}$ & $\begin{array}{l}\text { dry } \\
\text { harvest } \\
\text { (t/ha) }\end{array}$ & $\begin{array}{l}\text { dry } \\
\text { shelled } \\
\text { (t/ha) }\end{array}$ \\
\hline Height plant & 1,00 & & & & & & & & & & \\
\hline Number of leaves & 0,39 & 1,00 & & & & & & & & & \\
\hline Leaf Width $(\mathrm{cm})$ & $-0,05$ & 0,27 & 1,00 & & & & & & & & \\
\hline Leaf Length $(\mathrm{cm})$ & 0,38 & 0,37 & 0,23 & 1,00 & & & & & & & \\
\hline Stem Diameter $(\mathrm{cm})$ & 0,28 & 0,19 & $0,46^{*}$ & 0,32 & 1,00 & & & & & & \\
\hline Long Cobl (cm) & 0,18 & 0,22 & $-0,16$ & $-0,03$ & 0,16 & 1,00 & & & & & \\
\hline Stem Diameter $(\mathrm{cm})$ & $-0,36$ & $-0,36$ & 0,06 & $-0,07$ & $-0,26$ & $-0,14$ & 1,00 & & & & \\
\hline Number of Lines & & & & & & & & & & & \\
\hline $\begin{array}{l}\text { (Biji) } \\
\text { weight } 100(\mathrm{~g})\end{array}$ & $\begin{array}{l}-0,50^{*} \\
-0,04\end{array}$ & $\begin{array}{l}-0,27 \\
0,03\end{array}$ & $\begin{array}{l}0,14 \\
0,34\end{array}$ & $\begin{array}{l}-0,05 \\
0,26\end{array}$ & $\begin{array}{l}-0,33 \\
0,36\end{array}$ & $\begin{array}{l}-0,29 \\
0,38\end{array}$ & $\begin{array}{l}0,65 * * \\
0,07\end{array}$ & $\begin{array}{l}1,00 \\
-0,26\end{array}$ & 1,00 & & \\
\hline dry harvest (t/ha) & 0,05 & $-0,28$ & 0,35 & 0,06 & $0,48^{*}$ & 0,01 & $-0,02$ & $-0,09$ & 0,39 & 1,00 & \\
\hline dry shelled (t/ha) & 0,09 & $-0,18$ & 0,37 & 0,14 & $0,56 * *$ & 0,03 & $-0,11$ & $-0,17$ & 0,45 & $0,98 * *$ & 1,00 \\
\hline
\end{tabular}

Note: $*$ significantly different; $* *$ very different

The diameter of the stem is moderately correlated, positive and significantly different from the width of the leaf; moderate, positive and significantly different correlation with dry cheeks, ear diameter; as well as being moderately correlated, positive but not significantly different from the dry harvest and the number of row consoles. 


\subsection{Differences in Results}

HJ 21 Agritan, Nasa 29, Bisma of new superior varieties performance (NSV) had a plant height value lower than the NSV characteristic value, while the plant height value in Sukmaraga and Lamuru was slightly greater than the NSV characteristic value. The biggest difference in plant height was on Nasa 29 variety for $-82.8 \%$ (Table 7).

Table 7. Difference in results

\begin{tabular}{llrrrrr}
\hline & & \multicolumn{5}{c}{ Variety } \\
\cline { 3 - 7 } No & \multicolumn{1}{c}{ Parameter } & $\begin{array}{c}\text { HJ 21 } \\
\text { Agritan }\end{array}$ & Nasa 29 & Bisma & Sukmarga & Lamuru \\
\hline 1 & Plant height (\%) & $-61,1$ & $-82,8$ & $-79,4$ & 33,2 & 47,2 \\
2 & $\begin{array}{l}\text { Weight of 1000 seeds } \\
(\%)\end{array}$ & 113,6 & $-10,9$ & $-91,2$ & -10 & $-26,8$ \\
3 & Productivity (\%) & 0,6 & $-2,7$ & $-10,4$ & $-1,1$ & 0,2 \\
\hline
\end{tabular}

Note: a negative number (-) indicated a lower NSV performance than the characteristic value of NSV

In the weight parameter of 1000 seeds, Nasa 29, Bisma, Sukmarga and Lamuru were lower while HJ 21 Agritan was heavier than the characteristic value of NSV. HJ 21 Agritan varieties had the biggest difference 113.6\% (Table 7). For Productivity 29 Nasa, Bisma, Sukmaraga and Lamuru were lower, while HJ 21 Agritan was higher than the characteristic value of NSV. The biggest productivity difference in the Bisma variety was $-10.4 \%$.

\section{Feasibility Analysis of Hybrid Corn and Composite}

Cost analysis of corn farm is influenced by production, farming costs, selling price and purchase price of production facilities which greatly influences farm income / profits. Different levels of production are existing in several hybrid maize. The highest production was on Nasa 29 (9.2 t / ha), followed by HJ 21 Agritan with $6.3 \mathrm{t} / \mathrm{ha}$, and Sukmaraga (5.8 t / ha), Lamuru (5.5 t / ha), and lastly Bisma with $5.3 \mathrm{t} / \mathrm{ha}$ ). According to Aqil and Arvan (2014) the average yield of superior varieties of maize is between $5.25 \mathrm{t} /$ ha to $12.3 \mathrm{t} /$ ha. Then Palobo et al. (2019) stated that the yield of dry hybrid hybrid corn 5 new varieties on dry land namely Bima 19 URI (5.1 t / ha), Bima 20 URI (7.2 t / ha), Nasa 29 (7.2 t / ha) and Bisi 2 (6.5 t / ha). 
Table 8. Analysis of farm income for hybrid and composite corn on dry land in Regency, Merauke Papua

\begin{tabular}{|c|c|c|c|c|c|c|}
\hline \multirow{2}{*}{ Description } & \multirow{2}{*}{ Unit } & \multicolumn{5}{|c|}{ Varieties } \\
\hline & & HJ 21 Agritan & Nasa 29 & Bisma & Sukmarga & Lamuru \\
\hline \multirow[t]{2}{*}{ Production } & (kg / ha) & 6,300 & 9,200 & 5,300 & 5,800 & \\
\hline & & & & & & 5,500 \\
\hline Selling Price & $\begin{array}{r}(\mathrm{US} \$ / \\
\mathrm{kg})\end{array}$ & 0.35 & 0,35 & 0,35 & 0,35 & 0,35 \\
\hline Production Value & (US\$) & 2,205 & 3,220 & 1,855 & 2,030 & 1,925 \\
\hline \multicolumn{7}{|l|}{ Variable costs } \\
\hline - Seeds & (US\$) & 35.40 & 35.40 & 14.16 & 14.16 & 14.16 \\
\hline - Fertilizers & (US\$) & 107.95 & 107.95 & 107.95 & 107.95 & 107.95 \\
\hline - Pesticides & (US\$) & 46 & 46 & 46 & 46 & 46 \\
\hline - Workers & (US\$) & 361 & 361 & 361 & 361 & 361 \\
\hline \multicolumn{7}{|l|}{ fixed fee } \\
\hline $\begin{array}{l}\text { - Depreciation } \\
\text { of equipment }\end{array}$ & (US\$) & 1 & 1 & 1 & 1 & 1 \\
\hline $\begin{array}{l}\text { Total production } \\
\text { costs }\end{array}$ & (US\$) & 551.42 & 551.42 & 530.17 & 530.17 & 530.17 \\
\hline Net income & (US\$) & $1,653.58$ & $2,668.58$ & $1,324.17$ & $1,499.83$ & $1,394.83$ \\
\hline $\mathrm{R} / \mathrm{C}$ ratio & & 4.0 & 5.9 & 3.5 & 3.9 & 3.7 \\
\hline B / C Ratio & & 3.0 & 4.9 & 2.5 & 2.9 & 2.7 \\
\hline
\end{tabular}

Source: Primary Data (Processed) in 2019

Sudiana et al., 2012 stated several benefits of land use during the dry season for maize cultivation, including high yields, increased land productivity. To find out the amount of income, it must first be known the total of the revenue obtained, then reduced by the total costs 
that have been used from farming activities carried out. Income in farming activities is said to be beneficial if the revenue obtained is greater than the costs incurred by farmers. The following is a description of the cost of production, revenue, income and feasibility of farming. The results of the analysis of hybrid corn farm income can be seen in Table 8 .

In Table 8 above it appears that the total cost of hybrid corn farming is US\$ 551.42 or equal to Rp. 7,790,375 and composite corn is US\$ 530.17 or equal to Rp. 7,490,375 to the dry land of Merauke district. HJ 21 Agritan hybrid corn production of $6,300 \mathrm{~kg}$ of dry shelled at a price of Rp 5,000/kg (US\$ 0.35) obtained Rp 31,500,000 (US\$ 2,205) in revenue and income of Rp23,709,625 or US $\$ 1,653.58$ is obtained with R/C 4.0 or B/C 3.0. Then Nasa 29, namely $9,200 \mathrm{~kg}$ of dry shelled rice at a price of Rp 5,000/ $\mathrm{kg}$ (US\$ 0.35), it received Rp 46,000,000 (US\$ 3,220) in revenue, then an income of Rp 39,709,625 (US\$2,668.58) with R/C of 6.8 or $\mathrm{B} / \mathrm{C}$ of 5.8. Bisma composite corn production is $5,300 \mathrm{~kg}$ of dry shelled at a price of $\mathrm{Rp}$ $5,000 / \mathrm{kg}$ (US\$ 0.35) obtained revenue of Rp. 26,500,000 (US\$ 1,855) and an income of Rp. $19,009,625$ (US $\$ 1,324.17$ ) with R/C 3.5 or B/C 2.9. Next is Sukmaraga 5,800 kg of dry shelled rice with a price of $\mathrm{Rp} 5,000 / \mathrm{kg}$ (US\$ 0.35) obtained a revenue of $\operatorname{Rp} 29,000,000$ (US\$ 2,030) and an income of Rp 21,009,625 (US\$ 1,499.83) with R/C 3.9 or B/C 2.9. Then Lamuru 5,500 $\mathrm{kg}$ of dry shelled at a price of Rp 5,000/kg (US\$ 0.35) obtained Rp 27,500,000 (US\$ 1,925) in revenue then obtained an income of Rp 20. 009,625 (US\$1,394.83) with R/C 3.7 or B/C 2.7.

If seen from the total revenue, the allocation of farming costs for hybrid corn is US\$ 530.17 /ha of total revenue means that there are still more to receive rewards from farming HJ 21 Agritan US\$ 1,653.58 and Nasa 29 US\$2,668.58. By calculating the revenue and production costs, the HJ 21 Agritan and Nasa hybrid corn farming is very feasible to be developed with an R/C balance of 4.0 and 5.9, meaning that each expenditure of Rp.1,000 towards the given input will receive an income of Rp. 4,000 and Rp.5,900. While the Bisma, Sukmaraga and Lamuru composites are also feasible to be developed where each expenditure of Rp. 1,000, for the outputs, receives a profit of Rp. 3,500 Sukmaraga Rp. 3,900 and Lamuru Rp. 3,700.

Corn production is determined by the use of its inputs both seeds, fertilizers, pesticides and labor and planting systems. Analysis of the production function illustrates the relationship of production with its inputs wherein in this study to determine the adaptability of hybrid corn and composite NSV in Papua. Analysis of the production function is carried out to see the factors that influence the production of corn in the study location. In the initial production function, it is assumed with eight variables, namely land, seeds, fertilizer, medicine, other inputs, labor and the area of cultivation. According to Parlindungan et.al., (2016), factors affecting the production of corn farming on dry land are land, labor, urea fertilizer, phonska fertilizer, manure, farmers and varieties, while in Boediono (2000) costs include a measurement of the value of resources that must be sacrificed as a result of activities aimed at seeking profits.

\section{Conclusion}

The performance NSV of hybrid corn and composite tested both growth performance and performance results of the 5 (five varieties showed that the productivity of hybrid maize varieties of Nasa $29(9.2 \mathrm{t} / \mathrm{ha})$ and HJ 21 Agritan $(6.3 \mathrm{t} / \mathrm{ha})$ showed much higher productivity compared to composite corn in Bisma (5.3 t/ha), Lamuru (5.8 t/ha) and Sukmaraga (5.5 t/ha) 
varieties. Based on the results of the analysis of the farming of new high yielding varieties of hybrid maize and composites gave the highest profit of Nasa 29 hybrid corn, this is shown by the $\mathrm{R} / \mathrm{C}$ value of 5.9. However, both hybrid corn and composite corn based on R/C values above 3-4 so it is very feasible and provides benefits.

\section{Acknowledgement}

Thank you to the Agricultural Research and Development Agency, Ministry of Agriculture for providing financial assistance so that this research can be carried out. Dr. Ir. Yuliantoro Baliadi as Head of the Papua Agricultural Technology Study Center (2015-2018), Merauke Agricultural Technology Research (IP2TP) Development Team: Rodias Beda Legu, Nely Malla and Eko Binti Lestari as engineering who had assisted and escorted in observing and collecting data on Merauke during the research carried out.

\section{References}

Agricultural Research and Development Agency. (2009). General Guidelines of Corn PTT. Agricultural Research and Development Agency, Ministry of Agriculture. 20 things.

Aqil, M., \& Arvan, R. Y. (2014). Description of superior varieties of Plant Research Institute. Agricultural Research and Cereals Agency

Arifenie, F. N. (2013). Imports of Livestock Feed Corns Will Jump 86\%. http://industri.kontan.co.id/news/ Livestock Feed Corns Will Soar 86\% (Accessed, 12 June 2019)

Atman and Yardha. (2013). Adaptation of Four New Superior Corn Varieties in the Minimum Soil (Otm) System in West Sumatra.

Atman. (2015). Corn Production Strategies to Increase Corn Production. Plantaxia PublisherYogyakarta; $117 \mathrm{p}$

Balitserealia. (2012). National Superior Hybrid Corn, Cereals Research Institute. 2012 edition: 134.

Balitserealia. (2012). National Superior Hybrid Corn, Cereals Research Institute. 2012 edition: 134.

Boediono, (2000). Analysis of rice farming. (on line). Available, http://respository.ipb.ac.id/handle/1 23456789 / A08ana.pdf. Accessed June 20, 2018

Budiastuti, M. S. (2000). The Use of Triacontanol and Plant Spacing on Green Bean Plants (Paseolus radiantus 1). http://www.iptek.net.id

Center for Data and System of Information on Agriculture of the Ministry of Agriculture. (2017). Corn Agricultural Commodity Outlook. Jakarta (ID): Ministry of Agriculture.

Center for Research and Development, (2019). List of Superior Varieties [WWW Document]. URL http://www.litbang.pertanian.go.id/varietas/ (accessed 2.6.19)

Central Statistics Agency Papua. (2018). Papua in Figures: Harvest Area, Productivity, and 
Production of Corn in Papua Regency in 2011-2016. Papua

Erawati, B., T. R., Herawati, N., \& Widiastuti, E. (2013). The Role of Corn PTT in Increasing Production and Financial: Cases in Donggobolo Village, Woha District, Bima Regency, NTB. National Cereals Seminar, 267-278.

Handoko, S., \& Mulyadi, M. T. (2017). Adaptation Test for New Superior Varieties (Vub) of Hybrid Corn as an Effort to Utilize Suboptimal Land in Tanjung Jabung Timur Regency, Jambi Province. Proceedings of the 2017 National Suboptimal Land Seminar, Palembang 19-20 October 2017 "Development of Agricultural Science and Technology with Local Farmers for Optimizing Suboptimal Land

Hosen, N., Hardiyanto, M., Daniel, E., Mawardi, I., Manti, A., \& Harmaini (2013). Model of Increasing Production and Income of Environmentally Friendly Corn Farmers with a Dynamic System Approach in West Sumatra. Final report of AIAT West Sumatra (unpublished); $55 \mathrm{p}$.

Indonesian Central Statistics Agency. (2018b). Indonesian Statistics. Central Bureau of Statistics. Jakarta

Kaihatu, S. S., \& Pesireron, M. (2016). Adaptation of Several Corn Varieties in Dry Land Agroecosystem in Maluku. Food Crop Agriculture Research, 35, 2. https://doi.org/10.21082/jpptp.v35n2.2016.p141-148

Kaswan and Amzeri. (2011). Identification of Drought Tolerant Somaclonal Variants in Corn Populations Results of In Vitro Selection with Peg. Agrovigor Journal, 4(1). March 2011. ISSN 19795777.

Palobo, F., Hermana, M., \& Siska, T. (2019). Feasibility Analysis of hybrid corn farming on dry land in Merauke, Papua. Journal of Agricultural Social Economics and Agribusiness, Surakarta. ISSN 1829-9946, 16(1), September 2019

Palobo, F., Siska, T., \& Yuliantoro, B. (2018). Application of Composite Corn Farming Technology Innovation in the Border Region of Jayapura City. Potential Exploration for Agricultural Innovation in Border Areas. Jakarta Agricultural Research and Development Agency. ISBN 978-602-3442-10-2

Parlindungan, Y., Silitonga, S. H., Bonar, M. S., \& Rusastra, I. W. (2016). Efficiency Analyses of Maize Farming on Dry Land trough Implementation of Integrated Crop Management in West Java Province. Journal Informatika Pertanian, 25(2), 199-214. https://doi.org/10.21082/ip.v25n2.2016.p199-214

Probowati, R. A., Guritno, B., \& Sumarni, T. (2014a). Effect of Soil Crops and Plant Spacing on Weeds and Corn Crop (Zea mays L.), Journal of Crop Production, 2(8), 639-647.

Probowati, R. A., Guritno, B., \& Sumarni, T. (2014b). Effect of Soil Crops and Plant Spacing on Weeds and Corn Crop (Zea mays L.), Journal of Crop Production, 2(8), 639-647.

Purba, T. (2014). Study of Adaptation Test of Several New Superior Varieties of Maize in 
West Kalimantan Dry Land. Agros, 16(2), 385-390.

Research and Development Center. (2016). Description of Superior Varieties of Food Crops, 2016. Puslitbangtan Edition. ISBN: 978-979-1159-71-5, 70-95.

Robi "in, (2009). Technique of Computing the Comparison of Prima Tani Locations in Probolinggo Regency, East Java Agricultural Technology Study Center. Agricultural Engineering Bulletin, 14(2), 45-49.

Sarasutha, I. G. P. (2002). Corn Farming and Marketing Performance at the Production Center. Agricultural Research and Development Journal, 21(2), 38-47.

Sudiana, M. I., \& Gde Eka Martininggsih, N. G. A. (2012). Application of planting distance and semi-organic hybrid corn varieties. Ngayah Journal, 3(4), 34-43.

Supriyadi, E., Jaenudin A., \& Suciaty, T. (2013). Effect of Arbuscular Mycorrhizal Fungi (Pha) and Phosphate Fertilizers on P Absorption, Growth and Yield of Corn (Zea mays L.) Cultivar DK3. Journal of Agroswagati, 1(1), 42-54.

Supriyadi, E., Jaenudin, A., \& Suciaty, T. (2013). Effect of Arbuscular Mycorrhizal Fungi (Pha) and Phosphate Fertilizers on P Absorption, Growth and Yield of Corn (Zea mays L.) Cultivar DK3. Journal of Agroswagati, 1(1), 42-54.

Suryana, A., Darmadjati, D. S., Subandi, K., Zubachtirodin, K., \& Saenong, S. (2005). Prospects and Directions for Corn Agribusiness Development.

Sutardjo, S., \& Nawfetrias, W. (2013). Production Optimization of Four Hybrid Corn Varieties in Kertosono Nganjuk Regency. Indonesian Journal of Science and Technology, 14(1), 74-80.

Takdir A. M. R., Neni, I. M., \& Made, J. M. (2007). Genotype adaptation of prospective corn hybrids in several locations. Food Crop Agriculture Research. Bogor, 26(1), 20-25.

Vivianthi, E. L. (2012). Appearance of 21 Single Cross Hybrids Assembled Using Local Corn Varieties at Low Input Conditions, Journal of Natural Resources and Environmental Management Research, 1(3), 153-158.

Zamir, M. S. I., Ahmad, A. H., Javeed, H. M. R., \& Latif, T. (2011). Growth and yield Beheviour of Two Maize Hyhrid (Zea mays L,) Towards different plant spacing. Cercetari Agronimce in Moldavo, XLIV(2), 146-156. https://doi.org/10.2478/v10298-012-0030-9

\section{Copyright Disclaimer}

Copyright for this article is retained by the author(s), with first publication rights granted to the journal.

This is an open-access article distributed under the terms and conditions of the Creative Commons Attribution license (http://creativecommons.org/licenses/by/4.0/). 